\title{
HOW LONG ARE SAYINGS?
}

\author{
Anneli Baran
}

\begin{abstract}
We talk, communicate, chat, speak, and make utterances - all these synonymous verbs signify verbal communication and mark the same action. The action may also be expressed by means of set expressions, or more precisely, phrases or idioms. Words, phrases and syntactic units, or the sc. microtexts, are at our disposal. The issue may be also considered at another angle - namely, how short can a phrase be for it to preserve its contents? Compared to other short forms (proverbs, riddles), phrases are generally characterised as being shorter. It has been determined that the minimum length of a phrase is a combination of at least two fully semantic words. According to a common claim a phrase characterises a specific situation. Therefore, a phrase can only exist as a set expression in a context. Conceptualising phraseologisms, however, prompts the question of the 'obligatory' and 'facultative' constituents of a phraseologism, i.e. the issue of its form and, more importantly, of its defining. While discussing the motivation of phrasal expressions, scholars often refer to their opacity $v s$. transparency. But what would the ideal form be for which people possess sufficient background knowledge, including phraseological competence, which is required for understanding a given expression? What is the smallest number of words necessary for understanding an expression? Whether and to which extent can we find help in metalanguage framing a set phrase? In the article I will discuss the issues related to the study of phrasal semantics on the example of set phrases connected with the image of talking, narration, words, etc. The discussion will rely on material from the database of Estonian phrases.
\end{abstract}

Key words: literary language, metaphorical meaning, phraseological expressions, saying, semantics

\section{INTRODUCTION}

First I would like to make a point that my article will not be about the statistics of Estonian phrases, but as one of the compilers of the database of Estonian phrases, I will rather discuss my observations on the problematic areas connected with the semantic interpretation of phrases. Wishing to emphasise the specific short length characteristic of a phrase (Estonian kõnekäänd) as a short form of folklore, a more apposite title would perhaps be: How long can a phrase/phraseologism/idiom be? 
My article is based on the source material from the database of Estonian Phrases, or Eesti kõnekäänud ja fraseologismid - available at http://www.folklore.ee/ justkui, which is compiled by the work group of short forms of the Department of Folkloristics at the Estonian Literary Museum in the framework of the state financed topic Estonian and Kinsfolk Folklore: Heritage, Identity and Globalisation and the Estonian Science Foundation grants no. 2750 and 4945.

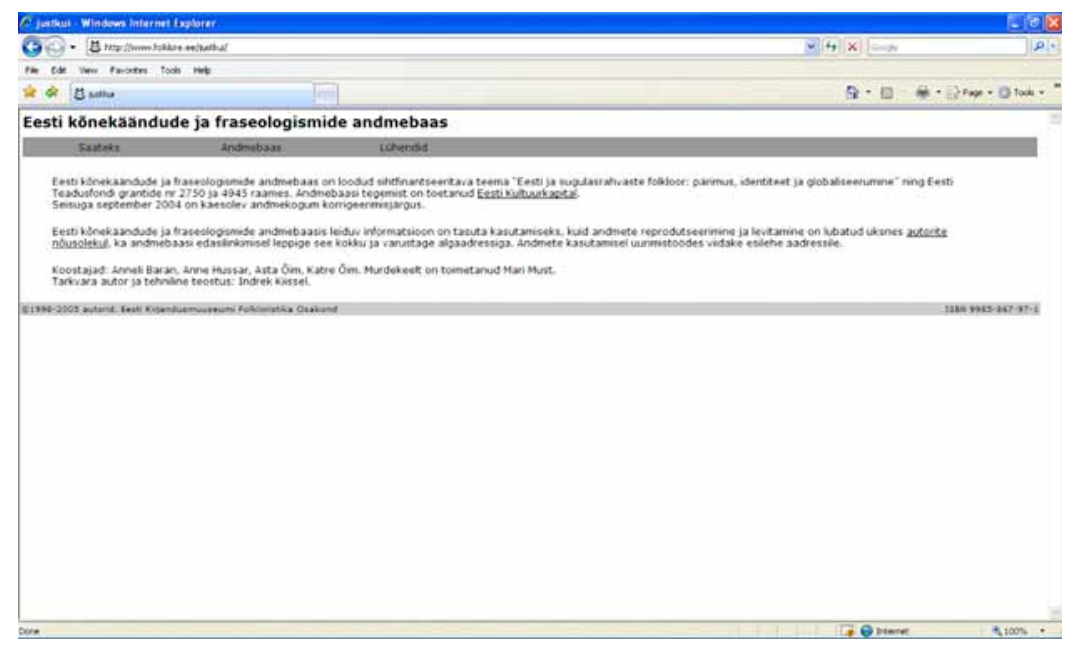

Figure 1. A view of the database of Estonian Phrases - the opening page.

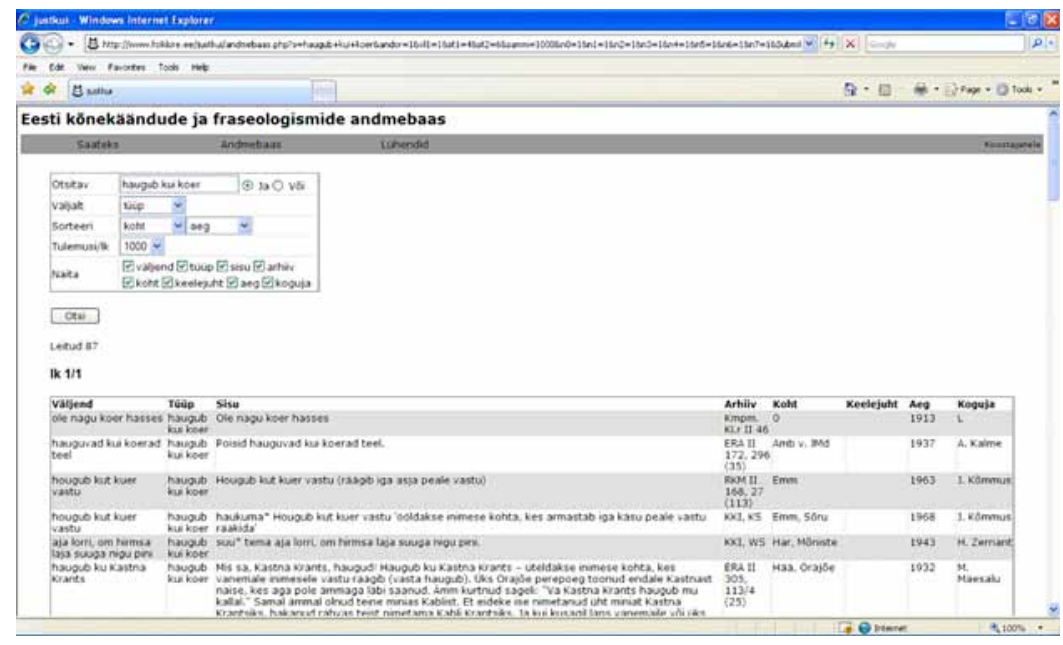

Figure 2. A view of the database of Estonian Phrases - the search page. 
The main research goal of our work group is the development of a comprehensive database of Estonian phrases and phraseologisms, and the preparation of the academic publication of Estonian Phrases (Eesti kõnekä̈̈nud). The database of Estonian phrases will serve as an effective additional material in the study of Estonian language, since the database entries contain Estonian dialects, and also oral and written Estonian language. The online digital database, which is still under construction, contains approximately 170,000 entries and this is not a finite number. Currently, the database enables search by type, expression, context, archive reference, the time and place of collection, collector and informant, i.e. additional data.

The majority of Estonian phrases were collected at the end of the nineteenth and the beginning of the twentieth century (this represented the peak of major folklore collection campaigns). This part of the material can be considered phrases in the traditional sense (in Estonian, kõnekäänd); the material collected more recently already constitute phraseological material, which is used (even) today. Phraseological fixed expressions/idioms reflect historical facts, biblical themes, folk culture and folk wisdom, superstition and facts from various areas of life involved in fostering material values. The collected material of short forms tends to be characteristically laconic, often including a comment in the line of was spread in olden times, was used in the past by older people, in old times by the younger generation, what people used to tell, or this word's meaning is clear and understandable in itself, don't know how to explain the exact meaning of the phrase. This renders folklorist's decisions often very speculative, since the material has been collected over a very long period of time. It is quite logical that the development of phrases is widely different: some phrases last longer, i.e., they continue to be used even today, some have disappeared from active use.

\section{ON PHRASE IMAGERY}

Phrases are the manifestations of figurative speech - in other words, they are binary in the semantic sense. That linguistic transfer plays a central role in phraseological formation is further confirmed by the fact that phraseology is largely based on metaphoric and metonymic transfer or double transfer. Free phrases or special word combinations which usually do not collocate are most prone to transfer.

It is a general knowledge that language is not a finite system, but is open to new developments and transformations, and the same applies to word meanings. The narrowing and expansion of meaning and semantic transfers are 
first and foremost connected with the denotative meaning of a word; changes in evaluativeness point to the associative aspect of a word meaning. In specific usage, a set expression may be functionally differentiated; i.e. a specific meaning depends on the communication situation in which the expression is used. In some cases the pragmatic specialisation of an expression may be associated with the semantic shifting of the individual meaning of single components within the general meaning.

In the following I will observe, and provide some examples, how a phraseological expression may lose its position because of the changes in the meaning of its core word (or image).

\section{SPEAKING, TALK, WORDS, ETC. AS THE TARGET DOMAIN OF A METAPHOR}

Since the phraseological material tends to be relatively heterogeneous in structure and semantics, I have decided to limit my discussion to conceptual groups that centre on a single core. In my presentation I will focus on expressions marking verbal (oral, word-related) activities. In the following I will present some observations which clearly indicate that expressions marking speaking or talking in the Estonian language are not very easy to analyse, which is often the case in the study of phrase semantics.

I will look further into phrases where the load is on the verb of metaphorical meaning. Since the latter is also included in dictionaries, and now known by its metaphorical meaning rather than the original meaning (which may no longer be known or included in dictionaries), the question is about its metaphorical nature, at least from the aspect of novelty. The question is whether this is a case of mere polysemy or something other than that? British lexicologist and phraseologist Rosamund Moon has noted that it is often quite difficult to differentiate between the synchronic or polysemic side of a semantic shift from the diachronic side. As a result of the diachronic development of language, the etymologically secondary metaphoric meaning of a word may become the only meaning, and the original etymological meaning may altogether disappear from the language (Moon 1998: 20). Also Arvo Krikmann has said that polysemy largely occurs in a metaphoric or metonymic transfer - depending on the disappearance of objects or their becoming topical in extralinguistic reality, the originally metaphoric meanings (i.e., those more difficult to access) may become neutral (Krikmann 2004: 158). Thus the definitions included in a dictionary may be built on generalisations based on the phraseological material. 
Now, let us take a closer look at such semantic tangles along with a few examples. ${ }^{1}$

The Estonian vocabulary includes the verb jahvatama ('grind', 'mill', 'prattle'), which the Estonian dictionary of literary language (EKSS 1991) provides the following definitions: (i) jahuks tegema peenestama ('grind', pulverize', 'reduce to fine particles'); (ii) alatasa närides sööma, peeneks närima ('always gnaw, 'masticate'); (iii) tüütuseni palju rääkima, latrama (kõnek) ('prattle endlessly', 'chatter'(colloquial)). There are two meanings here: original meaning and secondary meaning/metaphorical meaning. But if the metaphoric meaning of the verb has become general, there arises the question of its phraseological nature. These examples are non-phraselogical, for example they are nothing more than the use of a common verb in a sentence.

Küll ta jahvatab! ('Look at him/her prattle!')

Juokseb külasse jahvatama, sie või muidu eladagi. ('Runs to the village to chatter, can't live without it.')

Naised, kui kokku saavad, siis jahvatavad õhtani. ('Women! If they come together, they will chatter until the evening.')

Ei väsi ka need lõuad vahest ärajahvatamast! ('That these jaws never grow tired of chattering!')

Usually, a comment is added that räägib juttu, millel ei olnud mingit põhjust ega mõtet 'tells a story with no sense or purpose', nii öeldakse tühja jutu rääkija kohta 'this is what people say about those who talk nonsense', kogu aeg kõnelema 'talk incessantly'.

The archive materials also include these uses of the word which in their elaboration seem to have an additional meaning - the emphasis is laid on the result of overdoing something, and for that purpose hyperbole is used:

Jahvatab nõnda, et lõualuud kuluvad peas. ('Is chattering so that the jaws will get worn.')

Küll jahvatab, nõnda et lõualuud vahutavad peas. ('Look at him/her prattling, so that the jaws foam in the head.')

Jahvatab, nõnda et lõuad vahul. ('Chatters so that the jaws foam.')

Presumably, the metaphoric meaning of the Estonian verb jahvatama or grind is based on the Estonian simile jahvatab kui tatraveski ('grinds like a buckwheat mill'). The expression is most likely of German origin - der Mund geht wie ein Mühlwerk (Sachs \& Villatte \& Moser et al. 1921). This is generally quite typical of the older Estonian material. Characteristically of a popular 
idiom, this expression occurs in a number of variants. Here are some examples:

Suu potrab peas kui tatraveski. ('Mouth chattering like a buckwheat mill.')

Lõuad vatutavad peas kui tatraveski tiivad. ('Jaws foaming like sails of buckwheat mill.')

Jutt jookseb nagu tatratanguveski. ('Talks glibly like a buckwheat grain mill.')

Lasevad oma tatraveskid lahti, no siis läheb, nii et pladin taga kas vai ôtani. ('Let their buckwheat mills loose, then the chatter goes on until the evening.')

See puhub ja segab nagu tanguveski. ('This talks and meddles like a buckwheat mill.')

Padistab nagu veski võtabjahvatada. ('Chatters like a grinding mill') Patrab ja latrab kui tatraveski. Laterdab ja lädiseb jusku vajahuveski. Lõhvertab ja jahvatab nagu tanguveski. Jusku pudruveski poriseb ja patrab. ('Chatters and jabbers like a buckwheat mill. Jabbers-rattles like an old flour mill. Rattles and chatters like a grain mill. $\sim$ Like a porridge mill rattling and chattering.')

As the last four examples indicate, the verb jahvatama or 'grind' is supported and even replaced by descriptive verbs marking speaking.

Characteristically of phrases, some expressions tend to form a group of variants around them, in other words, the different formulations of the phrases are subject to greater variation. The variation may sometimes be quite considerable, and often an image occurs in very wide elaborations. Thus in the expressions that stand for talking nonsense or excessive activity the emphasis on the activities non-existent product: 'grinds with an empty mill' and 'empty mill grinding with no wind'.

There is also a somewhat more cryptic phraseological saying where the verb jahvatama or grind is retained, and the added component is a (grain) sack that need grinding, meaning 'for he who starts interfering with somebody else's talk':

Las ma jahvatan oma koti enne ära, jahvata sina siis! ('Let me grind my sack first, then you will get to grind!')

Las ma jahva, mul om matt makstud! ('Let me grind, my grain has been paid for!') 
Here are some other verbs which meaning demonstrates almost the same development than that of the verb jahvatama or 'grind'; the only exception here is that in Modern Estonian the secondary meaning of these two words have transformed into a single general meaning of the word (in dictionaries the word is still included with the secondary meaning). The latter, however, has become so neutral that the perceiving of the word as metaphorical and the phraseological nature of the expression it belongs to is quite dubitable.

Firstly, heietama ('to spin'), to which the Estonian dictionary of literary language (EKSS 1991) provides the following definitions: (i) heiet tegema, ketrama ('twist strands for spinning', 'spin'); (ii) piltl. pikalt-laialt millestki rääkima. ('figuratively, talk extensively about something for a long time').

Some examples here would be:

Kaua sa seda juttu heietad! ('How long are you going to spin the tale?')

Kui jutujärje oma käde sai, heietas seda õhtu otsa. ('When it was his turn to talk, he spinned it through the whole evening.')

Niikaua nad kuradid heietasid, kui nüid on plära väilas. ('Damn, they spinned the tale so long that it has become nonsense.')

While the first example sentence is no longer considered phraseological, i.e. the verb combination juttu heietama, or 'spin the tale' does not posses phraseological quality, the two following sentences do; the decisive factor here is the context.

Quite logically, the image of a spinning wheel is introduced in these expressions, resulting in a simile: ketrab vuriseb võristab kui vokk ('spins hums $\sim$ rattles like a spinning wheel') about 'a person who speaks much or very fast'. But here is the opposite meaning (or the shoe is on the other foot) in contrast with the meaning of the verb 'heietama' ('to spin yarn') which was 'to speak slowly'.

An advanced variant of this simile, which entails certain specification, goes as follows: suud käivad justkui vokirattad 'mouths are spinning like spinning wheels'. A saying has been recorded in East Estonia that contains an alliterative word combination vorr-vorrama in the meaning of 'talking nonsense': Mis sa vorr vorrad!, or mis sa vokk vurised! ('What are you, spinning wheel, rattling for?').

Secondly, I would like to draw your attention to the Estonian verb (archaism) lõugutama ('to brake, prattle, chatter'), to which the dictionary of Estonian literary language (EKSS 1993) provides the following meanings: (i) linavarsi lõugutiga murdma 'brake flax'; (ii) (tagaselja) vatrama, latrama, suud pruukima, väljakutsuvalt v. häbematult rä̈̈kima ('prattle, chatter, talk about somebody (behind his back), talk in a provocative or offensive manner'). 
Some examples here would be:

Küll lõugutab! ('Look at him prattling!')

Suu lõugutab peas. ('With the mouth chattering!')

Mis sa lõugutad, eile said lõugade pärast, tahad täna jälle saada! ('What are you prattling here - only yesterday got what you deserved for your jaws, and today you want more?')

Once again, the first example is nothing more than the use of a common verb in a sentence, while the following two expressions are phraseological sayings.

Next to the sayings with the core meaning, there are also expressions where the noun lõuguti, or 'flax braker', derived from the verb, is used to signify a person who is involved in the same activity in the metaphorical sense of the verb. The example here demonstrates a possible course of development of this expression, indicating that the saying may have been based on a simile.

suured lõuad kui kolgispuul > justkui vana linalõuguti üks lõugupuu kuradi inimeselõuk ('huge jaws like the flax braker's > like an old flax braker a flax braker damn human braker').

The latter example, which in the Estonian language is expressed by a compound word, is particularly interesting, as here the first component of the compound functions as if a specifying adjective - á la "a living flax braker". These expressions function as pejorative or derogatory names, of which the Estonian tradition is so rich in that they form a separate subcategory of phrases.

In Modern Estonian usage the verb more often used synonymously with lõugutama or brake prattle chatter is the descriptive verb lóksutama ('clack, rattle') and sayings associated with it. While in the "original" meaning the verb contains an allusion to the sound, i.e. to produce certain (metal) sounds, it is still most often used in the meaning of 'chatter, gossip, backbite', and usually together with the verb combination lõugu lõksutama 'chatter the jaws or yack'.

There are, of course, a number of sayings with variants of the verb lôksutama or rattle, which may be categorised under rhetoric exclamations (at least in this context), whereas some longer and more elaborate sayings contain an opposition: (intentional) excessive moving of jaws, on the one hand, and the role of wind as a natural force in this activity, on the other hand.

Mis sa laksutad oma puust lõugadega! ('What are you rattling your wooden jaws for?')

Ära logista oma puulõugu, praegu just suurt tuult pole! ('Don't clack your wooden jaws, there's not much wind at the moment!') 
Lõgistad sa ise oma lõugu või lõgistab neid tuul! ('Are you rattling your jaws or is it just wind?')

As the previously discussed examples suggest, in phraseology speaking and talking usually stand for excessive talking, chattering, interfering, lying - i.e. the words demonstrate an evaluative aspect. The evaluation is often expressed with hyperbole to further emphasise the disparaging attitude towards the activity.

The following verb that I will discuss is haukuma ('to bark'), to which the dictionary of Estonian literary language (EKSS 1991) provides definitions in the following order: (i) hariliku häälitsemise kohta ('the common sound of a dog'); (ii) kõnek. pahuralt, häbematult, järsult teistega kõnelema ('colloquial. to speak gruffly, impertinently, sharply to another person'). The verb has probably become the source for another Estonian verb, haugutama, meaning 'to scold, criticise, nag; to ridicule somebody's talk, mock'. Owing to this generalisation of meaning, the utterances Ära tule siia haukuma! 'Don't come here to bark!' and Muudkui haugub emale vastu 'Keeps barking back to his mother' are no longer considered phraseological. However, this is not the case in the following utterances:

Haukuda oskad, kas lakkuda ka oskad! ('You can bark, but can you lick too?')

Kaua sa urised, millal sa haukuma hakkad! ('How long are you going to growl before you'll start barking?')

Pane esimesed käpad ka maha, kui haugud! ('Get on all fours, if you're already barking like that!')

Meie pool on nisukesed alles pimedad, lakuvad piima, te pool juba hauguvad! ('From where I come from, they are still blind and suckle milk, but here they are already barking!')

Unlike the previously discussed verbs, in haukuma or 'bark' the meaning has not become neutral: here we can see a spectacular rise of an important component in its meaning, namely, the prototypic producer of the sound. This is a popular metaphor MAN IS AN ANIMAL, in this case A DOG. As becomes evident in the following examples, these sayings tend to have a negative connotation. When somebody speaks or talks too much, or chatters excessively, relatively direct and usually remarkably expressive orders or restrictions are given. Unlike the moralising of proverbs, these orders are didactic in a reverse way. In the archive materials the additional comments to the sayings are the following: lärmitsejale, kelle juttu kuulda ei taheta 'to a loudmouth, whom nobody wants 
to listen to', kui keegi asjata teise kallal lorises, 'if somebody was nagging on somebody else for no particular reason', vahele- või vastuhaukuja lapse hurjutamine 'scolding a child who interferes in other people's talk or barks back', kui kellegagi tapeldakse 'while brawling with somebody', aeti sõimuga minema 'was driven off with slander'.

Some examples here would be:

Peni, mis sa haugud! ('What are you barking at, dog!')

Krants, haugu metsa poole! ('Bark towards the woods, mongrel!')

Kutsu, kutsu - haugu ikka, aga ää hammusta. ('Doggy, doggy - bark, but do not bite!')

Kust pere peni sa oled, et võõrasse kohta haukuma tuled? ('Which family do you, dog, come from, that you dare to come barking in other people's house?')

Ust koju, kodu kuera tarvis ja sina siin! ('Shoo! Go home, the dog is needed at home and you're still here!')

Olõ no vaikki, sa olõt õks viil kutsik, sa ei tiiä' mia vana pini hauk! ('Be quiet, now, you're still a puppy, you don't know how an old dog barks!')

A to-m ütskõik, kas ma kõnõla vai pini hauk. ('But there was no difference, was I talking or was it the dogs barking.')

Padistab mes tuul tuond ja kuer haukund. ('Chattered like a wind rattling and the dog barking.')

Mis sa sest tähele paned, las külakoerad kilkavad! ('Why do you mind, let the village dogs yap!')

Jongib kõiksugu kuerasõnu. ('Mocks all kinds of dog words.')

Sõna siit, teine sealt, kolmas kirju koera saba alt. ('A word from here, a word from there, a word from under a dappled dog's tail.')

Läks, kurjad sõnad koertena kannul ('Left, with angry words chasing him like dogs.')

The last examples deserve closer attention because in these phrases it is not the dog and human who are set as equals, but the dog is identified with words (and dog as the utterer of the words). The latter are something that even appear to have the ability to move around, that is 'words chasing like dogs' (cf the Estonian phrases jutul jalad all 'the tale has legs'and jutt jookseb, literally, 'the talk is running'). 
I would also like to note that in Estonian phraseology, animal referents are among the most popular images: idioms and phrases about talking or speaking feature a number of other animals, mostly in the form of similes: podiseb nagu siil 'grunts like a hedgehog', piriseb kui sääsk 'buzzes like a gnat', vaagub kui vares 'croaks like a crow', kaagutab kui kana 'cackles like a hen', määgib nagu lammas 'bleats like a sheep', etc.

\section{LYING LIKE AN OLD WHITE}

On a further note about animal metaphors in the Estonian phrases, we could isolate a group with an interesting semantics - namely, association of valge hobune 'a white horse' with vale or valetamine 'a lie', or 'lying'.

Valetab, nii et valge hobune tuleb metsast välja. ('You are lying so that the white horse is coming out of the woods.')

Kas oled valet valge hobusega taga ajanud? ('Have you been chasing the lie on a white horse?')

Kas oled mind näind selle valge hobusega sõitmas, mis ma vale eest saand! ('Have you seen me riding the white horse that I got for this lie?')

The verb, which here has a direct meaning, has a purely structural function. At a superficial glance, at the very least, it seems that it is included only because of alliteration: valetab - valge, vale - valge. In some cases, and again for alliterative purposes, another adjective is added to the adjective valge, or 'white', namely vana, 'old', giving thus the Estonian phrase vana valge hobune or old white horse. In several older texts, the general name of the horse is omitted and vana valge, or 'the old white' stands for horse; this is the case of lexicalising a characteristic feature and using it instead of the object (for instance): Valetab nagu vana valge. ('Is lying like an old white.') and Joosõt ümbre nigu vana vale, kiil välä'. ('Was running around like an old lie, tongue hanging out.')

A comment to the archive text reads: suure valetaja kohta, kes alati palju valetab, 'about a big liar, who always lies'. This image is most likely of religious origin - the white horse stands for something unusual or unexpected, which leads to dangerous consequences, and is therefore the source of hyperbole.

The international spread of the image is further confirmed by the fact that the exact same image also occurs in the German tradition, where fahl means 'pale, dingy' (Röhrich 1973: 726): jmdn. auf einem fahlen Pferde ertappen 'catch somebody lying/give somebody the lie' and Wer einmal auf einem fahlen Pferde ertappt wird, dem glaubt man nicht leicht mehr 'Who's once caught telling a lie, is later not easily trusted'. 
To conclude, I would like to point out that the structure of saying, i.e. its components and the overall meaning of the phrase, is closely interrelated. The sayings accumulated in the archives with extremely laconic or even missing additional comments often remain incomprehensible for a user of Modern Estonian language - the motivation may be obscured by words which are no longer known or used (or those not used by the original meaning). That phraseologisms and idioms tend to be rather laconic in structure; understanding these requires a lot more additional or background knowledge. Regardless of the efforts, the study of imagery creation of phraseological expressions offers a wonderful opportunity to make observations about the development of language and the worldview behind it.

\section{COMMENTS}

1 I would like to bring to notice that all example texts here are presented with either literal or literal and semantic translations.

\section{REFERENCES}

Sachs, Karl \& Villatte, Césairi \& Moser, Karl \& Biel, Adolf \& Tönnies, Auguste \& Schmidt, Karl 1921. Enzyklopädisches französisch-deutsches und deutsch-französisches Wörterbuch: Hand-und Schulaufgabe: Mit Angabe der Aussprache nach dem phonetischen System der Methode Toussaint-Langenscheidt 2: Deutsch-französisch = Dictionnaire encyclopédique français-allemand et allemand-français: Édition à l'usage des ècoles, 2: allemand-français. Methode Toussaint-Langenscheidt. Berlin-Schöneberg: Langenscheidtsche Verlagsbuchhandlung.

EKSS 1991 = Raiet, Erich et al. (eds.). Eesti kirjakeele seletussõnaraamat, [Explanatory Dictionary of Standard Estonian.] Vol. 1 (A-J): 2 (bakhid-fosfororgaaniline). Tallinn: Valgus.

EKSS 1993 = Raiet, Erich et al. (eds.). Eesti kirjakeele seletussõnaraamat, [Explanatory Dictionary of Standard Estonian.] Vol. 3 (L-N): 2 (loor-mehestuma). Tallinn: Eesti Teaduste Akadeemia Keele ja Kirjanduse Instituut.

Krikmann, Arvo 2004. Koestler, Raskin, Attardo ja teised: Lingvistiliste huumoriteooriate uuemaist arenguist. Reetor 4. Tartu: Eesti Kirjandusmuuseum. In English: Krikmann, Arvo 2006. Contemporary Linguistic Theories of Humour. Folklore Vol. 33. Tartu: Eesti Kirjandusmuuseum.

Moon, Rosamund 1998. Fixed Expressions and Idioms in English: A Corpus-Based Approach. Oxford Studies in Lexicography and Lexicology. Oxford: Clarendon Press \& New York: Oxford University Press.

Röhrich, Lutz 1973. Lexikon der sprichwörtlichen Redensarten, Vol. 1-2. Freiburg: Herder. 